УДК 159.923+159.9:616

DOI: $10.33184 / \mathrm{NShvb}-2021-11-22.5$

Гилязева Асна Маратовна, магистрант факультета психологии Башкирского государственного университета Научный руководитель - Халфина Р. Р.

\title{
К ВОПРОСУ О КЛИНИКО-ПСИХОЛОГИЧЕСКИХ ОСОБЕННОСТЯХ ПОДРОСТКОВ, СКЛОННЫХ К АУТОАГРЕССИВНОМУ ПОВЕДЕНИЮ
}

Аннотация. Данная статья посвящена актуальной проблеме аутоагрессивного поведения подростков. Рассмотрена проблема изучения клинико-психологических особенностей подростков, склонных к аутоагрессивному поведению.

Ключевые слова: аутоагрессия, аутоагрессивное поведение, клинико-психологические особенности, подростки.

Важность исследования клинико-психологических особенностей личности, склонной к аутоагрессивному поведению, обуславливается тем, что в современном мире все чаще встречаются случаи самоповреждающего поведения среди подростков всех социальных классов, вне зависимости от таких факторов, как: полнота семьи, доходы семьи, вероисповедание, традиции и культура семьи, социальное положение и т.д.

На данный момент в психологической науке наблюдается недостаточность исследования клинико-психологических особенностей подростков с аутоагрессивным поведением. Однако такие исследования крайне важны не только для понимания причин аутоагрессии подростков, но и для работы педагогов, психологов и других участников учебновоспитательного процесса. 
С одной стороны, большое внимание сейчас уделяется изучению суицидального поведения подростков, что можно объяснить увеличением частоты случаев суицидальных попыток среди подростков и целенаправленностью профилактики данного проявления аутоагрессивного поведения в обществе. В связи с этим проводятся исследования с целью изучения причин суицидального поведения подростков.

Однако гораздо меньше внимания уделяется особенностям несуицидального самоповреждающего поведения подростков. Если в основе суицидального поведения лежат осознанные мысли и действия личности, то несуицидальное самоповреждающее поведение зачастую не осознается подростком и является проявлением его внутриличностных проблем.

Подростковый возраст является наиболее сензитивным к формированию неадаптивных форм поведения, к которым можно отнести аутоагрессивное поведение (рискованное поведение, употребление психоактивных веществ, телесные модификации, нарушения пищевого поведения). Также этот возрастной период является самым критическим периодом в развитии личности. Распространенность аутоагрессивных актов поведения среди подростков могут быть связаны с такими причинами, как: эмоциональная неустойчивость, импульсивность, повышенная возбудимость, раздражительность, отрицание себя, плохие отношения со сверстниками и др. [1, с.128].

Можно выделить следующие факторы, которые могут повлиять на формирование аутоагрессивного поведения у подростков: перенос негативных эмоций и агрессии по отношению к окружающему мира на себя, непринятие своего тела, недостаток близости со значимыми людьми, чувство вины, демонстративное поведение.

Как отмечают специалисты, действия аутоагрессивного характера наблюдаются как при различных формах психических расстройств и соматических заболеваний, так и при нормальном развитии [3, с. 71,72].

До сих пор не изучена природа аутоагрессивного поведения. Мы можем лишь условно выделить четыре основные теоретические концепции: социальную, психологическую, психопатологическую и физиологическую [2, с. 2].

Также А.А. Реаном было введено понятие «аутоагрессивный паттерн поведения», в котором он рассматривает 4 блока: 
1) характерологический (рассматривает взаимосвязь уровня аутоагрессии с такими чертами личности, как: депрессивность, невротичность, интроверсия, демонстративность и педантичность);

2) самооценочный (связывает проявления аутоагрессивного поведения с заниженной самооценкой;

3) интерактивный (отражает взаимосвязь склонности личности к аутоагрессии со способностью или неспособностью к социальной адаптации и межличностному взаимодействию);

4) социально-перцептивный - (рассматривает влияние восприятия личности другими людьми на формирование аутоагрессивных паттернов поведения).

Таким образом, мы можем наблюдать недостаточность изученности клинико-психологических особенностей подростков с аутоагрессивным поведением, что обуславливает необходимость в данных исследованиях.

\section{Список использованных источников}

1. Ипатов А.В. Психологические особенности подростковой аутодеструкции // Акмеология. 2014. №3 (51). С. 128 - 132;

2. Исагулова Е. Ю. Развитие когнитивных навыков в подростковом возрасте с целью преодоления аутоагрессивных паттернов поведения // Медицинская психология в России. 2020. Т.12, № 1 (60) С. 2 - 3;

3. Чуева Е. Н. Самоповреждающее поведение детей и подростков // Вестник КРАУНЦ. Гуманитарные науки. 2017. №1 (29). С. 71 - 77.

(C) Гилязева А. М., 2021 